\title{
Methodological Bias in Estimates of Strain Composition and Straying of Hatchery-Produced Steelhead in Lake Michigan Tributaries
}

\author{
MEREDith. L. BARTRON* \\ Department of Fisheries and Wildlife, Michigan State University, \\ 13 Natural Resources Building, East Lansing, Michigan 48824, USA and \\ U.S. Fish and Wildlife Service, Northeast Fishery Center, \\ Post Office Box 75, Lamar, Pennsylvania 16848, USA \\ DAve R. Swank AND Edward S. Rutherford \\ School of Natural Resources and Environment, \\ University of Michigan, Ann Arbor, Michigan 48109, USA \\ KIM T. SCRIBNER \\ Department of Fisheries and Wildlife, Michigan State University, \\ 13 Natural Resources Building, East Lansing, Michigan 48824, USA
}

\begin{abstract}
Steelhead Oncorhynchus mykiss were first introduced into the Great Lakes in the late 1800s. Subsequently, natural recruitment of steelhead from spawning runs in streams across the basin has been regularly supplemented by hatchery production of strains derived from widely dispersed locales within the species' native range. Estimates of hatchery contributions to the spawning runs of naturalized populations may be underrepresented by observations of marked fish, as not all hatchery fish are marked prior to release. To assess the potential bias in estimates of the hatchery contribution to steelhead spawning runs in four major rivers in Michigan, we used scale pattern analysis (SPA) to identify nonmarked hatchery fish and multilocus genotypes to estimate the proportional contributions of each hatchery strain to spawning runs. The four hatchery strains currently stocked are significantly genetically distinct (mean $F_{\mathrm{ST}}=0.077$ ), making it possible to identify specific strains by use of likelihood-based assignment tests. The differences between direct (mark observations) and indirect (SPA and genetic analysis) estimates of hatchery contribution were mainly due to variations in the percentage of hatchery fish marked by states prior to release and the potential for confusion between certain marks and injuries. By combining direct and indirect assessment methodologies, we estimated that the percentage of hatchery fish returning to the four rivers ranged from $13 \%$ to $31 \%$ of total spawning runs. The large contribution of hatchery fish to nonstocked rivers differed significantly from expectations of strain-specific stocking rates across the Lake Michigan basin and for individual streams, indicating high amounts of straying into Michigan streams.
\end{abstract}

Many fisheries exist in waters that extend across multiple state, provincial, and national boundaries and are jointly managed by several management agencies. Different agencies often utilize different assessment methodologies, making coordination and multi-jurisdictional fisheries data comparison difficult. Such an example is found for the Lake Michigan steelhead Oncorhynchus mykiss fishery, in which the four surrounding states use identifying marks (e.g., fin clips, maxilla clips, or a combination thereof) to identify hatchery-origin steelhead. All states that stock steelhead in the Lake Michigan basin mark a portion of the hatchery

\footnotetext{
* Corresponding author: meredith_bartron@fws.gov

Received May 5, 2003; accepted March 5, 2004
}

steelhead prior to release (Table 1). Mark data are used to estimate hatchery strain-specific rates of straying (the proportion returning to spawn in a river other than the natal river), and to estimate the contribution of both hatchery-produced and naturally produced steelhead to the recreational fishery in Lake Michigan and its tributaries. Accurate assessments of the straying and relative contribution of hatchery fish are likely compromised due to the duplicate use of specific marks for multiple strains, and because not all individuals of hatchery origin are marked by each state prior to stocking. Additionally, overestimates of certain hatchery strains are likely, as general strain-specific marks may be confused with hooking injuries (i.e., maxilla clips), resulting in an upward bias in abundance estimates. 
The use of multiple assessment techniques to identify strain contributions to mixed populations has been widespread in fisheries management. Traditional techniques (scale pattern analysis [SPA], coded wire tags, fin clips, otolith analysis) have been useful for placing individuals to geographic locations (Candy and Beacham 2000), hatchery strain (Burzynski 1999), or stocking location (Hard and Heard 1999; Thedinga et al. 2000). Genetic stock identification techniques are also commonly used to discriminate among stock contributions to fisheries (Pella and Milner 1987; Scribner et al. 1998; Beacham et al. 2000; Hansen et al. 2001; Potvin and Bernatchez 2001).

Molecular techniques have become a common tool in fisheries management. Molecular analysis of the degree of population structure and assessment of strain or population contribution to fisheries (Marshall et al. 1991; Scribner et al. 1998; Beacham et al. 2000) represent just a few applications. In the absence of physical marks, the ability to assign individuals to population or strain of origin is based on the degree of population differences in allele frequencies for a suite of genetic markers (Cornuet et al. 1999), and has been particularly useful in fisheries assessments. Molecular markers, when used in association with more traditional fish identification techniques, can increase classification accuracy and improve the ability to determine the potential for hatchery and wild fish interactions.

Steelhead were first introduced into Lake Michigan in the late 1800s (Biette et al. 1981). Adult steelhead return to natal rivers in the fall and spring, and spawn from early to late spring. Spawning habitat in Wisconsin, Indiana, and Illinois is marginal or limited in distribution (Seelbach 1986). Accordingly, reproduction in rivers primarily occurs in Michigan tributaries due to the abundance of favorable spawning habitat. After hatching, juveniles spend 1-3 years in the river before emigrating as smolts to Lake Michigan (Seelbach 1986). Steelhead spend 1-3 years in the lake or ocean environment before returning to spawn in the natal river (Seelbach 1986). In their native habitat, adults are believed to stray to rivers other than the natal river for spawning, but at low rates (Quinn 1993). Straying rates were historically estimated at 6\% in Lake Michigan (Stauffer 1955) and 3-10\% in Lake Huron (Dodge 1972).

Spawning runs of steelhead in many tributaries to Lake Michigan are currently maintained by both natural reproduction and hatchery supplementation. Hatchery production averages 1.8 million fish annually (Table 1), and is used to supplement natural recruitment to enhance river and lake recreational fisheries. High levels of stocking and changes in age at release (fall fingerling to large yearling; Seelbach 1987) in some states have likely increased juvenile survival and led to greater returns of adult hatchery steelhead (Seelbach 1987; Rand et al. 1993; Seelbach and Miller 1993).

The stocking location, size, and age of juvenile steelhead can produce large variations in survival to the smolt stage and in the straying rates of spawning adults. Stocking locations of steelhead have been widely distributed around the Lake Michigan basin. Estimated probability of survival of stocked juveniles in Lake Michigan can vary from 0.0001 over 2 years for a fingerling stocked into a marginal river (suboptimal trout habitat) to 0.9 for a large yearling $(>150 \mathrm{~mm})$ stocked into a trout river (Rand et al. 1993). The degree of straying of anadromous salmonids has been found to be impacted by stocking location within a river (upstream versus river mouth; Thedinga et al. 2000), date of release (Pascual et al. 1995), size of juveniles at the time of release (Pascual et al. 1995), and location of stocking if different from the rearing location (Pascual et al. 1995).

Our objectives were to assess the degree of bias in assessments of hatchery strain composition of spawning runs and to determine whether the amount of strain-specific straying was consistent with stocking level and release origin. We examined several hypotheses pertaining to straying patterns of hatchery steelhead for Lake Michigan tributaries. The null hypothesis we tested was that steelhead of hatchery origin stocked into Lake Michigan represent a single panmictic population, and that the abundance of adults of hatchery origin is proportional to the amount stocked. We would therefore expect the population to be composed of (1) adults of natural origin and (2) hatchery fish present in proportions that reflect the relative stocking proportions. Support for this general hypothesis comes from the fact that adult steelhead migrate large distances in the Pacific Ocean, and therefore migration within the comparatively small confines of the Lake Michigan basin should not be limiting. Additionally, steelhead are widely distributed throughout open-water habitats in the Lake Michigan basin. We further wished to examine potential differences in hatchery strain composition in each of four surveyed rivers.

\section{Methods}

Stocking history.--Stocking records for the Lake Michigan basin were obtained for the years be- 
TABLE 1.-Average number per year (SEs in parentheses) of four strains of juvenile steelhead stocked by the states bordering Lake Michigan from 1993 to 1997. The juvenile year-classes represent the expected returns to Lake Michigan tributaries during fall 1998 and spring 1999. In addition to the actual numbers stocked, the table shows the smolt equivalents (SEquiv.), defined as the actual numbers of fish stocked adjusted for size- and age-specific survival (Rand et al. 1993). Over the period in question, Wisconsin, Illinois, and Indiana marked 33, 100, and 15\%, respectively, of their steelhead releases. Michigan marked 100\% of its releases from 1995 to 1997 but an undetermined percentage in 1993-1994.

\begin{tabular}{|c|c|c|c|c|c|c|}
\hline \multirow[b]{2}{*}{ Hatchery strain } & \multicolumn{2}{|c|}{ Michigan } & \multicolumn{2}{|c|}{ Wisconsin } & \multicolumn{2}{|c|}{ Illinois $^{\mathrm{b}}$} \\
\hline & Total & SEquiv. & Total & SEquiv. ${ }^{a}$ & Total & SEquiv. \\
\hline Michigan & $\begin{array}{l}524,895 \\
(28,826)\end{array}$ & $\begin{array}{l}437,061 \\
(34,047)\end{array}$ & & & & \\
\hline Skamania & $\begin{array}{r}76,580 \\
(19,769)\end{array}$ & $\begin{array}{r}41,439 \\
(16,979)\end{array}$ & $\begin{array}{l}159,374 \\
(59,571)\end{array}$ & $\begin{array}{l}4,782 \\
(1,786)\end{array}$ & $\begin{array}{l}39,502 \\
(22,185)\end{array}$ & $\begin{array}{l}395 \\
(222)\end{array}$ \\
\hline Gnaraska & & & $\begin{array}{l}265,041 \\
(116,366)\end{array}$ & $\begin{array}{l}6,382 \\
(1,601)\end{array}$ & & \\
\hline Chambers Creek & & & $\begin{array}{l}206,285 \\
(49,268)\end{array}$ & $\begin{array}{l}5,464 \\
(670)\end{array}$ & & \\
\hline
\end{tabular}

a The large disparities between the total and adjusted stocking numbers for Wisconsin, Indiana, and Illinois reflect higher expected rates of mortality for smaller (fingerling) juvenile size-classes.

b Illinois stocked the Skamania strain in 1996 and 1997.

tween 1993 and 1997, when hatchery steelhead returning to rivers in 1998-1999 would have been stocked. Specifically, for each state in the Lake Michigan basin, information was collected regarding the hatchery strain stocked, the number of individuals stocked (marked and nonmarked), size and age of the hatchery juveniles stocked, location of stocking, and the type of mark used. The specific stocking records were obtained from Burzynski (1999; Wisconsin data), the Indiana Department of Natural Resources (J. Palla, personal communication), the Michigan Department of Natural Resources (http://www.michigan.gov/dnr), and the Illinois Department of Natural Resources (S. Krueger, personal communication).

Hatchery marks observed in each of four Michigan rivers were identified to strain of origin based on stocking records obtained from each state agency that stocked steelhead into the Lake Michigan basin (Table 1). Due to the use of a single mark to designate both the Michigan strain and the Indiana Skamania strain, all fish with this mark were classified as Michigan strain. Due to the small portion of Indiana Skamania steelhead marked prior to release $(15 \%$; Table 1$)$, the bias introduced by combining the information would be small. Therefore, individuals identified as Skamania strain by mark observations represent only the Wisconsin Skamania strain. To determine the hatchery composition of the nonmarked fish, we collected fin clips (for genetic analysis) and scale samples (for SPA) from all nonmarked individuals.

We developed expectations for the proportional contributions of hatchery-origin adults to spawning runs based on the total numbers of juveniles stocked. However, there is likely to be increased mortality of hatchery steelhead stocked as fingerlings in comparison to those stocked at a larger size in Lake Michigan (Seelbach 1987). To account for differential mortality to the smolt stage (smolt equivalents) based on age and size at stocking (i.e., small yearlings $[<150 \mathrm{~mm}$ ] versus large yearlings $[\geq 150] \mathrm{mm}$ ) and stocking location, the number of hatchery juveniles stocked were adjusted as described by Rand et al. (1993). These adjustments allowed estimated abundances of hatchery fish stocked into the Lake Michigan basin to be standardized and to more accurately represent the proportional abundance of each strain. Adjustments were made by multiplying the number stocked by an estimate of percent survival to the smolt stage. The resulting number of smolt equivalents was used as the total expected abundance of each hatchery strain in each river.

Sampling locations and tissue collection.-Adult steelhead were sampled from four rivers in Michigan during the fall 1998 and spring 1999 spawning runs. Samples were obtained by electroshocking and creel sampling on spawning grounds in the Pere Marquette River, Bear Creek, and the Platte River, and at a weir in the Little Manistee River (Figure 1). Samples were collected on multiple dates over the course of the spawning season to ensure that representative samples were obtained from spawning adults. The Pere Marquette and Little Manistee rivers were sampled during the 
TABLE 1.-Extended.

\begin{tabular}{|c|c|c|c|c|c|c|}
\hline \multirow[b]{2}{*}{ Hatchery strain } & \multicolumn{2}{|c|}{ Indiana } & \multirow[b]{2}{*}{ Total } & \multirow[b]{2}{*}{$\%$ of total } & \multirow[b]{2}{*}{ SEquiv. } & \multirow[b]{2}{*}{$\%$ of total } \\
\hline & Total & SEquiv. & & & & \\
\hline Michigan & $\begin{array}{l}151,518 \\
(26,208)\end{array}$ & $\begin{array}{l}1,110 \\
(2,446)\end{array}$ & 676,413 & 37.2 & 438,171 & 68.4 \\
\hline Skamania & $\begin{array}{l}396,729 \\
(57,860)\end{array}$ & $\begin{array}{l}143,884 \\
(1,281)\end{array}$ & 672,185 & 36.9 & 190,500 & 29.7 \\
\hline Gnaraska & & & 265,041 & 14.6 & 6,382 & 1.1 \\
\hline Chambers Creek & & & 206,285 & 11.3 & 5,464 & 0.9 \\
\hline All strains & & & $1,819,924$ & & 640,517 & \\
\hline
\end{tabular}

fall and spring, whereas Bear Creek and the Platte River were sampled only in the spring. Because the fall and spring runs were not genetically different and because the proportional hatchery contributions to the fall and spring runs were the same (Bartron and Scribner 2004), fall and spring samples were combined for the Pere Marquette and Little Manistee rivers.

Scale pattern analysis.-We used SPA to estimate the stream growth and residence time of juveniles to determine whether nonmarked individuals were of wild or hatchery origin. Specifically, we used Seelbach and Whelan's (1988) ratio 23, a metric of scale growth. Ratio 23 is the ratio of (1) the distance from the first stream annulus to the fifth circulus, measured towards the focus (band 2) to (2) the distance from the first stream annulus to the fifth circulus, measured towards the scale margin (band 3; Seelbach and Whelan 1988). Distributions of ratio values from fish of known origin (hatchery or river) were used to determine a point at which hatchery-origin fish could be differentiated from river-origin fish (Seelbach and Whelan 1988). We also considered the number of years an individual spent in a river to improve the classification of individuals whose ratio 23 value fell within the area of overlapping distributions of known-origin individuals. Hatchery yearlings migrate downstream to Lake Michigan within a year after stocking, whereas juvenile steelhead produced in the wild may reside in the stream for more than 1 year prior to smoltification (Seelbach 1987). Incorporation of juvenile stream age probably reduced errors in misidentification of stream origin fish with ratio 23 estimates close to 0.70 . Therefore, any steelhead with a ratio 23 value of 0.80 or less and that also had a stream age of 2 or greater was classified as being of wild origin. Otherwise, individuals with ratio 23 values of 0.70 or greater were considered to be of hatchery origin (Seelbach and Whelan 1988). To test whether the observed numbers of hatchery steelhead present in each river system differed significantly from numbers expected based on the proportions stocked into Lake Michigan, the expected number of steelhead was based on smolt equivalent estimates to account for differential survival of juveniles stocked at different sizes, ages, and locations in the Lake Michigan basin.

Genetic analysis.-Fin clips from each of the four hatchery strains currently stocked in the basin were obtained for genetic analysis. Small pieces of tissue were taken from the caudal fins of adult steelhead returning to each of the four study rivers. Only individuals that lacked hatchery identifying marks were sampled for genetic analysis and SPA. Samples were preserved in $95 \%$ ethanol or were dried in scale envelopes. The sample DNA was extracted based on PureGene (Gentra, Inc.) protocols. Microsatellite loci used for analysis were Ogola and Ogo4 (Olsen et al. 1998), One 10 and One 11 (Scribner et al. 1996), Omy77 (Morris et al. 1996), Otsl (Banks et al. 1999), and Ots100 (Nelson et al. 1998). Polymerase chain reaction (PCR) was conducted in $25-\mu \mathrm{L}$ reaction volumes with $100 \mathrm{ng}$ of DNA, $1 \times$ PCR buffer $(0.1 \mathrm{M}$ tris $-\mathrm{HCl}$, pH 8.3, $0.015 \mathrm{M}$ of $\mathrm{MgCl}_{2}, 0.5 \mathrm{M}$ of $\mathrm{KCl}, 0.1 \%$ gelatin, $0.1 \%$ nonidet $\mathrm{P}-40,0.1 \%$ Trition-X 100), $0.2 \mathrm{mM}$ of deoxynucleotide triphosphates, $0.6 \mathrm{mM}$ of fluorescently labeled forward primer, $0.6 \mathrm{mM}$ of unlabeled reverse primer, and 0.3 units of Taq polymerase. The PCR reactions 

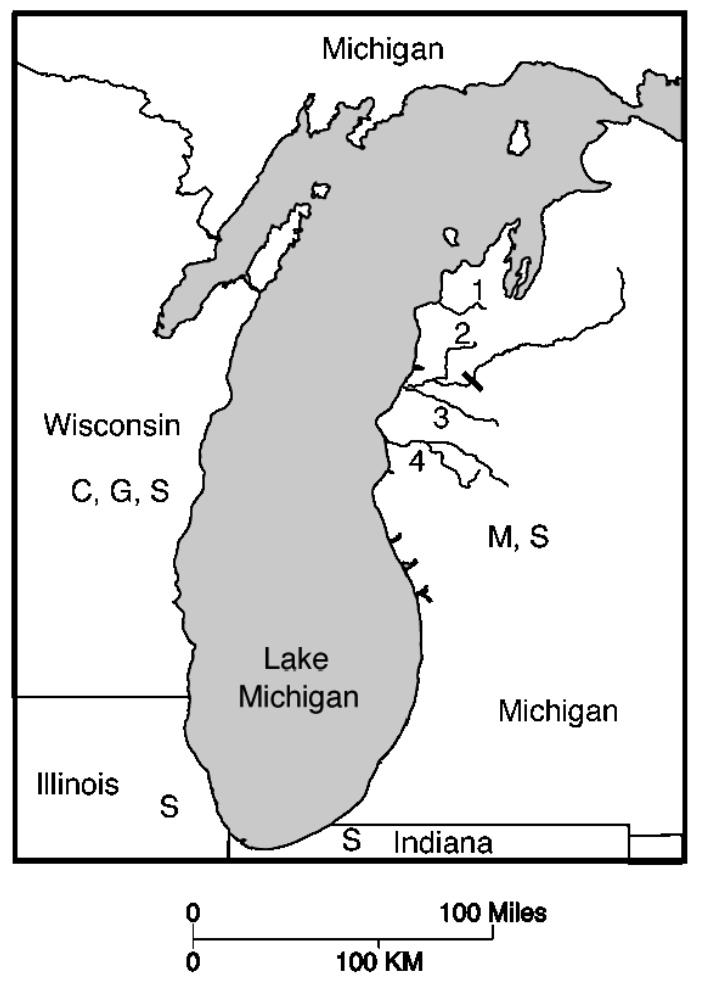

FIGURE 1.-Map of the Lake Michigan basin, showing the locations of Michigan rivers where steelhead populations were sampled: (1) the Platte River, (2) Bear Creek (a tributary of the Manistee River), (3) the Little Manistee River, and (4) the Pere Marquette River. The bar that intersects the Manistee River corresponds to Tippy Dam, which prevents upstream migration of adult steelhead. Sampling locations for these rivers were distributed throughout river reaches located downstream of dams. Hatchery strains sampled were the Chambers Creek (C), Ganaraska (G), Skamania (S), and Michigan (M) strains; states that stock these strains are indicated on the map.

for $\mathrm{Ogo}_{0}$ were conducted in $25-\mathrm{mL}$ volumes; the above protocol was followed except for use of an additional $2.5 \mathrm{mM}$ of $\mathrm{MgCl}_{2}$ and primer concentrations of $0.5 \mathrm{mM}$. The PCR reactions for Ots 100 were conducted in $25-\mathrm{mL}$ volumes, and the above protocol was again followed except that an additional $12.5 \mathrm{mM}$ of $\mathrm{MgCl}_{2}$ was used and primer concentrations of $0.5 \mathrm{mM}$ were used. The PCR reactions for all loci utilized an initial denaturing step at $94^{\circ} \mathrm{C}$ for $2 \mathrm{~min}$, followed by 30 cycles of $94^{\circ} \mathrm{C}$ for $1 \mathrm{~min}$, annealing temperature for $1 \mathrm{~min}$, an extension at $72^{\circ} \mathrm{C}$ for $1 \mathrm{~min}$, and a final extension period of $2.5 \mathrm{~min}$. Annealing temperatures were as follows: $56^{\circ} \mathrm{C}$ for $\mathrm{Ogola}, 54^{\circ} \mathrm{C}$ for $\mathrm{Ogo}$, $54^{\circ} \mathrm{C}$ for $O m y 77,52^{\circ} \mathrm{C}$ for One $\mu 10,62^{\circ} \mathrm{C}$ for
One $\mu 11,54^{\circ} \mathrm{C}$ for Ots 1 , and $58^{\circ} \mathrm{C}$ for Ots 100 . Denaturing $6 \%$ acrylamide gels were used for electrophoresis. Genotypes were visualized on a Hitachi FMBIO II scanner. Molecular weight standards and samples from individuals of known genotype were run on each gel to standardize scores.

Statistical analysis.-Pairwise estimates of the degree of interstrain differentiation in allele frequency $\left(F_{\mathrm{ST}}\right)$ were determined by use of FSTAT software (version 2.9.3.2), and we used Bonferroni corrections to adjust nominal $\alpha$ levels for multiple comparisons (Rice 1989). Individuals were assigned to strain of origin with likelihood-based assignment tests (Rannala and Mountain 1997). Estimates of assignment accuracy were based on the "leave-one-out" technique for resampling the strain baseline samples (Efron 1983). Estimates of statistical confidence in individual assignment decisions were based on posterior probabilities (Pritchard et al. 2000; Blanchong et al. 2002).

Determination of hatchery contribution.-To determine the percentage of wild-origin adult spawners based on mark observations for each river, we subtracted the number of marked hatchery fish collected from the total number of fish collected. Strain totals for the SPA-genetics method were based on individuals without marks. We calculated 95\% confidence intervals for the wild fish contributions estimated by direct and indirect methods (Sokal and Rohlf 1995) from the equation

$$
1.96 \cdot \sqrt{\frac{p(1-p)}{n}},
$$

where $p$ is the proportion of wild fish and $n$ is the number of fish sampled. Direct (mark) and indirect (SPA and genetics) methods of hatchery strain identification were combined by summing the numbers of individuals assigned to each strain based on both methods. The SPA-genetics estimates of hatchery-strain-specific contribution for the Little Manistee River were extrapolated when combined with mark observations because only a subsample of the fall and spring runs was analyzed by use of genetic methods.

Expected strain-specific counts of stocked fish were based on the yearly average of numbers stocked into Lake Michigan between 1993 and 1997 for the Lake Michigan basin (Table 1) and for each river (Table 2). The yearly averages of the numbers stocked were adjusted for age- and size-specific survival to calculate the number of smolt equivalents (Rand et al. 1993). The Ganaraska and Chambers Creek strains were not 
TABLE 2.-Numbers of Michigan and Skamania strain steelhead stocked into four Michigan rivers from 1993 to 1997. Smolt equivalents are defined as the actual number of fish stocked adjusted for size- and age-specific survival (Rand et al. 1993).

\begin{tabular}{|c|c|c|c|c|c|c|}
\hline \multirow[b]{2}{*}{ River } & \multirow[b]{2}{*}{$\begin{array}{l}\text { Year(s) } \\
\text { stocked }\end{array}$} & \multirow[b]{2}{*}{$\begin{array}{c}\text { Strain(s) } \\
\text { stocked }\end{array}$} & \multicolumn{4}{|c|}{ Number stocked } \\
\hline & & & Total & $\begin{array}{l}\text { Average } \\
\text { per year }\end{array}$ & $\begin{array}{c}\text { Smolt } \\
\text { equivalents }\end{array}$ & $\begin{array}{c}\text { Average } \\
\text { smolt } \\
\text { equivalents } \\
\text { per year }\end{array}$ \\
\hline Pere Marquette & $\begin{array}{l}1993-1997 \\
1993-1994\end{array}$ & $\begin{array}{l}\text { Michigan } \\
\text { Skamania }\end{array}$ & $\begin{array}{l}51,400 \\
14,100\end{array}$ & 14,048 & 46,260 & 9,252 \\
\hline Little Manistee & 1997 & Michigan & 500 & 100 & 450 & 90 \\
\hline Bear Creek (Manistee) & 1993-1997 & $\begin{array}{l}\text { Michigan } \\
\text { Skamania }\end{array}$ & $\begin{array}{l}237,673 \\
120,066\end{array}$ & 72,348 & 213,906 & 42,781 \\
\hline Platte & Not stocked & & & & & \\
\hline
\end{tabular}

stocked into rivers in Michigan; therefore, individuals belonging to these strains were not expected in any of the study rivers. Comparisons were only made between the observed and expected numbers based on stream- and strain-specific stocking for Michigan-strain individuals found in the Little Manistee River, and for Michigan- and Skamania-strain individuals found in the Pere Marquette River, Bear Creek, and the Platte River.

Three tests were conducted to determine how observed hatchery strain composition compared with expected composition based on stocking levels. The number of hatchery individuals of each strain was first compared among rivers to test for differences in proportional abundance by river and by strain. Fisher's exact tests (Statistical Analysis System software; SAS Institute 1999) were performed to test among-stream heterogeneity. Second, observed counts of hatchery steelhead of each strain were compared (chi-square tests) to the numbers expected based on stocking proportion in the Lake Michigan basin. Finally, we used chisquare tests to compare the observed counts of individual strains to expected values based on the yearly average number stocked into each river. Be-

TABLE 3.-Pairwise estimates of interstrain variance in allele frequency (mean $F_{\mathrm{ST}}$ over seven microsatellite loci) for four hatchery strains of steelhead stocked into Lake Michigan. Asterisks denote significant differences $(P<$ $0.05)$.

\begin{tabular}{lccc}
\hline & \multicolumn{3}{c}{ Hatchery strain } \\
\cline { 2 - 4 } \multicolumn{1}{c}{$\begin{array}{c}\text { Hatchery } \\
\text { strain }\end{array}$} & Skamania & $\begin{array}{c}\text { Chambers } \\
\text { Creek }\end{array}$ & Ganaraska \\
\hline Skamania & & & \\
Chambers Creek & $0.045^{*}$ & & \\
Ganaraska & $0.117^{*}$ & $0.060^{*}$ & \multirow{2}{*}{$0.037^{*}$} \\
Michigan & $0.127^{*}$ & $0.080^{*}$ & 0.00 \\
\hline
\end{tabular}

cause not all strains were stocked in each of the rivers examined, chi-square tests were not possible for each strain $\times$ river comparison.

\section{Results}

\section{Stocking History}

Approximately 1.8 million juvenile steelhead were stocked into the Lake Michigan basin annually between 1993 and 1997 (Table 1). The number of individuals of a given strain stocked by each state was generally consistent among years. Adjustments to the total number of juveniles stocked into the basin according to age, size, and location of stocking (smolt equivalents) reduced the annual number of juvenile steelhead stocked to 640,517 (Table 1). The proportion of juvenile steelhead marked prior to release varied by state during 1993-1997. Beginning in 1995, Michigan began marking all hatchery-origin individuals. Illinois also marked $100 \%$ of juvenile steelhead prior to release from hatcheries (Table 1). Wisconsin marked approximately $33 \%$ of the hatchery juveniles, and Indiana marked approximately 15\% of hatchery juveniles.

Of the four rivers examined in this study, only

TABLE 4.-Estimates of classification accuracy for likelihood-based assignment tests of four strains of Lake Michigan hatchery steelhead (Blanchong et al. 2002). Percentages on the diagonal are the proportions of individuals of each strain that were correctly reclassified to strain of origin based on seven microsatellite loci.

\begin{tabular}{lcccc}
\hline & \multicolumn{4}{c}{ Strain reclassified as: } \\
\cline { 2 - 5 } \multicolumn{1}{c}{$\begin{array}{c}\text { Strain of } \\
\text { origin }\end{array}$} & Michigan & Skamania & $\begin{array}{c}\text { Chambers } \\
\text { Creek }\end{array}$ & Ganaraska \\
\hline Michigan & $86.7 \%$ & & & $13.3 \%$ \\
Skamania & & $98.2 \%$ & $1.8 \%$ & \\
Chambers Creek & & $5.0 \%$ & $95.0 \%$ & \\
Ganaraska & $6.7 \%$ & & $1.7 \%$ & $91.7 \%$ \\
\hline
\end{tabular}


TABLE 5.-Numbers and percentages of Lake Michigan steelhead adults from four hatchery strains that returned to four Michigan rivers. Strains were indentified based on mark observations and a combination of genetic analysis and scale pattern analysis (SPA) to identify nonmarked hatchery-produced steelhead. Strains include Michigan (MI), Skamania (SK), Ganaraska (GA), and Chambers Creek (CC). The estimated percentages of wild adults are presented with 95\% confidence intervals $(\mathrm{CI})$.

\begin{tabular}{|c|c|c|c|c|c|c|c|c|c|}
\hline \multirow[b]{3}{*}{ River } & \multicolumn{6}{|c|}{ Mark observations } & \multirow{2}{*}{\multicolumn{3}{|c|}{$\frac{\text { SPA-genetics }}{\text { Number and } \% \text { hatchery }}$}} \\
\hline & \multicolumn{5}{|c|}{ Number and $\%$ hatchery } & \multirow{2}{*}{$\begin{array}{l}\% \text { wild } \\
\text { (CI) }\end{array}$} & & & \\
\hline & $n$ & MI & SK & GA & $\mathrm{CC}$ & & $n$ & MI & SK \\
\hline \multicolumn{10}{|c|}{ Fall and spring runs combined } \\
\hline Pere Marquette River & 117 & $\begin{array}{l}2 \\
2 \%\end{array}$ & $\begin{array}{l}4 \\
3 \%\end{array}$ & $\begin{array}{l}1 \\
1 \%\end{array}$ & $\begin{array}{l}5 \\
4 \%\end{array}$ & $\begin{array}{l}91 \% \\
(0.00)^{\mathrm{b}}\end{array}$ & 105 & $\begin{array}{l}1 \\
1 \%\end{array}$ & 0 \\
\hline Little Manistee River & 5,294 & $\begin{array}{l}283 \\
5 \%\end{array}$ & $\begin{array}{l}35 \\
1 \%\end{array}$ & 0 & $\begin{array}{l}35 \\
1 \%\end{array}$ & $\begin{array}{l}93 \% \\
(0.00)\end{array}$ & 158 & $\begin{array}{l}30 \\
19 \%\end{array}$ & $\begin{array}{l}6 \\
4 \%\end{array}$ \\
\hline \multicolumn{10}{|c|}{ Spring run only } \\
\hline Bear Creek & 70 & $\begin{array}{l}3 \\
4 \%\end{array}$ & $\begin{array}{l}3 \\
4 \%\end{array}$ & $\begin{array}{l}1 \\
1 \%\end{array}$ & $\begin{array}{l}6 \\
9 \%\end{array}$ & $\begin{array}{l}80 \% \\
(0.01)\end{array}$ & 56 & $\begin{array}{l}3 \\
5 \%\end{array}$ & 0 \\
\hline Platte River & 79 & $\begin{array}{l}1 \\
1 \%\end{array}$ & $\begin{array}{c}8 \\
10 \%\end{array}$ & 0 & $\begin{array}{l}12 \\
15 \%\end{array}$ & $\begin{array}{l}73 \% \\
(0.01)\end{array}$ & 58 & $\begin{array}{l}2 \\
3 \%\end{array}$ & 0 \\
\hline Total & & 289 & 50 & 2 & 58 & & & 36 & 6 \\
\hline $\begin{array}{l}\text { Strain contribution } \\
\text { to hatchery total }\end{array}$ & & $73 \%$ & $12 \%$ & $1 \%$ & $14 \%$ & & & $69 \%$ & $12 \%$ \\
\hline
\end{tabular}

a Wisconsin is the only state that has a strain-specific clip for the Skamania strain; therefore, direct observations of marks are for the Wisconsin Skamania strain only.

b Confidence intervals are based on Rao (1998).

c We observed all marked individuals but only performed genetic analysis on a subsample of them. To combine mark observations and SPA-genetics methods, strain-specific contributions estimated by use of SPA-genetics were extrapolated proportionally to the entire sample.

the Platte River was not stocked between 1993 and 1997 (Table 2). The Little Manistee River was stocked with a small number of individuals of the Michigan strain. Portions of the Pere Marquette River and Manistee River drainages (of which Bear Creek is a tributary) were stocked with large numbers of both Michigan and Skamania hatchery strains (Table 2). However, Bear Creek was not directly stocked, and only one tributary of the Pere Marquette River (Ruby Creek, located near the mouth) was stocked.

\section{Genetic Identification of Hatchery Strains}

Significant differences in allele frequency were observed among the four hatchery steelhead strains stocked in the Lake Michigan basin $(P<$ 0.05; Table 3). Differentiation between the Skamania strains produced by Indiana and Wisconsin was low and not significant $(P>0.05$; data not shown). Accordingly, estimated contributions of Skamania-strain steelhead based on genotypic data represent cumulative contributions from both states. Interstrain comparisons indicated that the greatest differentiation was between the Michigan and Skamania hatchery strains (mean $F_{\mathrm{ST}}=0.127$; Table 3 ). The smallest difference in allele frequencies was between the Michigan and Ganaraska strains (mean $F_{\mathrm{ST}}=0.037 ; P<0.05$; Table
3). Levels of differentiation among strains were sufficiently large to provide accurate individual classification for each strain (range, 86.7-98.2\%; Table 4).

\section{Estimated Strain-Specific Contribution Based on Mark Observation}

Direct estimates of the contribution of individual hatchery strains to adult steelhead spawning runs in four Michigan rivers ranged from $0 \%$ to $15 \%$ of the samples collected from each run. Total hatchery contributions (all strains combined) when extrapolated across an entire spawning run varied from $9 \%$ of the fall and spring runs in the Pere Marquette River to $27 \%$ of the spring run in the Platte River (Table 5). Marks identifying each of four hatchery strains were observed in the Pere Marquette River and Bear Creek (Table 5). The Little Manistee and Platte rivers both contained individuals from the Michigan, Skamania, and Chambers Creek hatchery strains.

\section{Estimated Strain-Specific Contribution Based on Genotype and SPA}

We estimated that, of the nonmarked fish collected, the contributions of hatchery steelhead ranged from $3 \%$ to $26 \%$ of the total spawning run based on SPA-genetic analysis (Table 5). Hatch- 
TABLE 5.-Extended.

\begin{tabular}{|c|c|c|c|c|c|c|c|c|}
\hline \multicolumn{3}{|c|}{ SPA-genetics } & \multicolumn{6}{|c|}{ Combined mark SPA-genetics } \\
\hline \multicolumn{2}{|c|}{ Number and $\%$ hatchery } & \multirow{2}{*}{$\begin{array}{l}\% \text { wild } \\
\text { (CI) }\end{array}$} & \multicolumn{5}{|c|}{ Number and $\%$ hatchery } & \multirow{2}{*}{$\begin{array}{c}\% \text { wild } \\
\text { (CI) }\end{array}$} \\
\hline GA & $\mathrm{CC}$ & & $n$ & MI & SK & GA & $\mathrm{CC}$ & \\
\hline \multicolumn{9}{|c|}{ Fall and spring runs combined } \\
\hline 2 & 0 & $97 \%$ & 117 & 3 & 4 & 3 & 5 & $87 \%$ \\
\hline $3 \%$ & & $(0.03)$ & & $3 \%$ & $3 \%$ & $3 \%$ & $4 \%$ & $(0.06)$ \\
\hline 4 & 1 & $74 \%$ & $5,294^{\mathrm{c}}$ & 1,220 & 225 & 125 & 66 & $69 \%$ \\
\hline $3 \%$ & $1 \%$ & $(0.01)$ & & $23 \%$ & $4 \%$ & $2 \%$ & $1 \%$ & $(0.01)$ \\
\hline \multicolumn{9}{|c|}{ Spring run only } \\
\hline 3 & 0 & $89 \%$ & 70 & 6 & 3 & 4 & 6 & $73 \%$ \\
\hline $5 \%$ & & $(0.08)$ & & $9 \%$ & $4 \%$ & $6 \%$ & $9 \%$ & $(0.11)$ \\
\hline 0 & 0 & $97 \%$ & 79 & 3 & 8 & 0 & 12 & $71 \%$ \\
\hline & & $(0.05)$ & & $4 \%$ & $10 \%$ & & $15 \%$ & $(0.10)$ \\
\hline 9 & 1 & & & 1,232 & 240 & 132 & 89 & \\
\hline $17 \%$ & $2 \%$ & & & $73 \%$ & $14 \%$ & $8 \%$ & $5 \%$ & \\
\hline
\end{tabular}

ery contribution of nonmarked fish (all four strains combined) was 3\% in the Pere Marquette River and $26 \%$ in the Little Manistee River (Table 5). The Michigan strain was present in all four rivers. Individuals of each of the four hatchery strains were found in the Little Manistee River (Table 5). Individuals of the Michigan and Ganaraska strains were found in the Pere Marquette River and Bear Creek (Table 5).

\section{Combined Direct and Indirect Estimates of Strain-Specific Contribution}

To estimate the total hatchery contribution to spawning runs in the four rivers, a combination of hatchery mark observation and SPA-genetic assignment was used to examine the composition of two separate groups of steelhead (marked and nonmarked). Individual strain contribution to spawning runs ranged from $0 \%$ to $23 \%$ (Table 5). With the exception of the Platte River, each of the four hatchery strains was observed in the examined rivers. Total hatchery contribution ranged from $13 \%$ in the Pere Marquette River to $31 \%$ in the Little Manistee River (Table 5). In Bear Creek, hatchery individuals contributed $27 \%$ of the spawning run; in the Platte River, hatchery individuals contributed $29 \%$ of the spawning run (Table 5). Estimates of Michigan-strain contribution to the spawning runs of the Pere Marquette and Platte rivers were similar based on both mark observation and SPA-genetics (Table 5). Individuals of the Skamania strain were estimated as present in all rivers based on mark observations (Table 5). However, SPA-genetic analysis identified Skamania strain only in the Little Manistee River and in a greater abundance in the fall and spring runs than was estimated by mark observations (4\% versus $1 \%$, respectively; Table 5).

Observed numbers of steelhead with the Ganaraska strain mark represented $1 \%$ of the spawning runs in the Pere Marquette River and Bear Creek (Table 5). The SPA-genetic analysis identified individuals of the Ganaraska strain in the Pere Marquette River (3\% of the total run), the Little Manistee River (3\%), and Bear Creek (5\%; Table 5) spawning runs. The Chambers Creek strain contributed to the spawning runs of Bear Creek (9\%) and the Platte River (15\%; Table 5) based on mark observations, whereas this strain was not present in the SPA-genetic analysis of nonmarked individuals from those rivers. The SPA-genetic analysis did not detect the Chambers Creek strain in the Pere Marquette River, but mark observations estimated a $4 \%$ contribution by this strain (Table 5). The Chambers Creek strain's contribution to the Little Manistee River was comparable for mark observation and SPA-genetic analysis identification methods (1\%; Table 5).

Of the rivers examined in this study, only the Platte River was not stocked with hatchery individuals, and the Little Manistee River was stocked with very low numbers of individuals. However, sizable portions of hatchery-derived adults were observed during spawning. This included appre- 
ciable numbers of hatchery individuals stocked by other states around the basin. The Little Manistee River had the highest contribution of hatchery steelhead between the two nonstocked rivers (31\%; Table 5). The Platte River also had a large hatchery contribution to the spawning run $(29 \%$; Table 5), despite the lack of stocking there.

\section{Straying of Hatchery Strains into Rivers in Michigan}

Comparison of the observed and expected hatchery contributions to the spawning runs of the four study rivers provided evidence of homing in Lake Michigan steelhead. We found significant differences among rivers in the strain composition of hatchery-origin individuals $\left(\chi^{2}=181.4\right.$; df $=$ 9; $P<0.0001)$. Chi-square tests between the observed and expected contributions of each hatchery strain pooled across all rivers indicated a significant deviation $\left(\chi^{2}=1,249.2 ;\right.$ df $=3 ; P<$ 0.001 ) from values expected based on the proportion of smolt equivalents stocked into the Lake Michigan basin. River-specific chi-square tests indicated significant differences between the observed contributions of hatchery-origin steelhead and the values expected based on Lake Michigan stocking proportions for the Pere Marquette River $\left(\chi^{2}=5.3 ; \mathrm{df}=1 ; P<0.05\right)$, the Little Manistee River $\left(\chi^{2}=1,015.7 ; \mathrm{df}=3 ; P<0.001\right)$, Bear Creek $\left(\chi^{2}=5.0 ; \mathrm{df}=1 ; P<0.05\right)$, and the Platte River $\left(\chi^{2}=10.5\right.$; df $\left.=1 ; P<0.05\right)$. Due to the low contribution of the Ganaraska and Chambers Creek strains to the total percentage of hatchery smolts stocked into Lake Michigan, and the low number of hatchery-origin individuals observed in the Pere Marquette River, Bear Creek, and the Platte River, no individuals from these two strains were expected in these rivers. Therefore, chisquare comparisons based on Lake Michigan stocking proportions of these two strains were only made for the Little Manistee River.

The observed proportions of Michigan- and Skamania-strain individuals differed from the proportions stocked into each river. The proportions observed in the spawning run differed significantly from stocking proportions for the Pere Marquette River $\left(\chi^{2}=5.9\right.$; df $\left.=1 ; P<0.05\right)$ but not for Bear Creek. As the Michigan and Skamania strains are the only hatchery steelhead strains stocked into the Pere Marquette River and Bear Creek drainages, statistical comparisons were not made for the Chambers Creek or Ganaraska strains, despite observations of individuals with marks specific to those strains.

\section{Discussion}

Comparisons of straying estimates derived from mark observations with those based on SPA-genetic methods indicated that potential biases exist when mark data alone are used to estimate hatchery contributions to steelhead spawning runs. We documented nonuniformity among states bordering Lake Michigan in terms of the proportions of steelhead juveniles who received marks (Table 1). As such, assessment information based solely on marks may misrepresent strainspecific estimates of abundance or contribution to fisheries.

The use of hatchery marks (e.g., fin clips, maxilla clips, or a combination of marks) that are easily confused with injuries, such as those resulting from hooking, may bias estimates by overestimating the contribution of strains that possess those marks. The Wisconsin Skamania and Chambers Creek strains are identified by a clipped left or right maxilla (Burzynski 1999). Estimates for the left-maxilla-clipped Chambers Creek strain were consistently higher than those of the Ganaraska strain, which are identifiable by clips on both maxillae (additional marks are sometimes used in combination with the maxilla clips; Burzynski 1999). Estimates of Skamania-strain contribution primarily consist of steelhead from Wisconsin, although Indiana and Michigan both stock the Skamania strain and mark a portion of the stocked fish (Table 1). Because only one-third of Wisconsin's hatchery fish are marked prior to release, estimates of the nonmarked steelhead are expected to be approximately two times greater than estimates based on mark observations alone. However, analysis of nonmarked individuals indicated smaller contributions for the single-maxilla-clipped steelhead. Assuming that marking does not affect straying, a portion of single-maxilla-clipped individuals may not belong to the Chambers Creek or Skamania strains, but rather represent river-origin individuals with hooking injuries. Hooking injury can lead to the loss of maxillae, especially among juveniles. The existence of bias in estimates for the Chambers Creek strain due to mark and injury confusion is supported by the fact that multiple individuals with the singlemaxilla clip were observed in Bear Creek and the Platte River (Table 5), but the presence of this strain was not corroborated by the SPA-genetic techniques (Table 5). Similarly, though the overall contribution of the Skamania strain was similar for both mark observation and SPA-genetic tech- 
niques (12\% of hatchery observations), mark observations identified the Skamania strain in all four rivers, whereas the SPA-genetic techniques indicated that this strain was present only in the Little Manistee River (Table 5).

Straying is an adaptive life history characteristic of salmonids, including steelhead. Therefore, the presence of individuals of hatchery origin belonging to strains not stocked into a particular system was expected. However, the observed extent of straying was not expected (Table 5). It has been noted that hatchery individuals may stray at higher rates than are found in naturally occurring populations (Waples 1991). The Little Manistee River has been stocked with very low numbers of individuals, and the Platte River was not stocked during the time period examined. However, the mouths of these drainages are geographically proximate to heavily stocked systems, therefore increasing the potential for the straying of fish during fall and spring spawning migrations.

We found significant differences among rivers in the strain-specific composition of hatchery-origin steelhead. Among-river heterogeneity in strain contribution to spawning runs indicates that adult hatchery contribution is not randomly distributed between each river system. Additionally, significant differences in the observed and expected numbers of hatchery-origin individuals in spawning runs for all rivers indicated nonuniform distribution of hatchery strains due to differences in abundance of hatchery strains observed among rivers. For example, proportions of hatchery-origin individuals found in the Little Manistee River, Bear Creek, and the Platte River were significantly different from the proportions of each strain stocked into Lake Michigan. However, the proportion of hatchery-origin individuals in the Pere Marquette River did not differ from the proportion stocked into Lake Michigan. This result may be biased by the relatively small contributions of the Chambers Creek and Ganaraska strains to the Lake Michigan hatchery-origin steelhead population, and by the relatively low observed number of hatchery-origin individuals in the Pere Marquette River.

There are positive and negative implications associated with our finding that high proportions of Michigan spawning runs were derived from hatchery fish stocking by other states. On one hand, Michigan experiences an "embarrassment of riches." If strain composition of spawning adults is consistent with strain contributions to the creel, then Michigan anglers are reaping the benefits of resources expended by other states. However, introgression between hatchery strains will lead to the breakdown of among-strain genetic differences, potentially resulting in the loss of the differences in heritable life history traits (e.g., run timing) that currently exist between the strains and that provide managers with greater management options.

The large contribution of certain hatchery strains to the spawning runs in Michigan increases the potential for introgression among hatchery strains and between naturalized and hatchery populations. Reisenbichler and Phelps (1989) hypothesized that reduction in among-stream genetic diversity of Washington steelhead populations was due to the widespread stocking of hatchery steelhead and the resulting introgression with the native populations. Introgression between naturalized steelhead populations in Michigan and the Michigan hatchery strain has been proposed as a primary cause for the lack of significant genetic differentiation among drainages (Bartron and Scribner 2004). Of particular concern is the contribution of hatchery-origin individuals from strains other than the Michigan strain to the fall and spring spawning runs of the Little Manistee River. The Little Manistee River serves as the source for gametes used in propagation of the Michigan strain (Seelbach 1987).

When accounting for differential survival of the various ages and stages of fish stocked into the Lake Michigan basin based on estimated survival (Rand et al. 1993), we found that approximately $39 \%$ (Table 1) of the stocked juveniles survive to the smolt stage. Due to the small size of the fingerling stage at stocking, low survival rates indicate that hatchery stocking programs are producing more steelhead for stocking purposes than are needed; if the juvenile survival estimates are correct, agencies could better devote resources to producing smaller numbers of larger, older juveniles, which have better survival rates (Seelbach 1987; Rand et al. 1993). Further studies to evaluate the impacts of stocking location, age, and size on juvenile steelhead survival could be extremely important to evaluation of steelhead hatchery supplementation programs in Lake Michigan.

Concerted management efforts to utilize hatchery marks that are not easily confused with injuries and to mark all hatchery-produced individuals may reduce bias in mark-derived information. By using both mark observation and SPA-genetic methods, we were able to estimate the contribution of natural reproduction to spawning runs in four rivers in 
Michigan. Although approximately 1.8 million juvenile steelhead are stocked into the Lake Michigan basin each year, the contribution of natural recruitment to the spawning runs for the four rivers we examined was greater than the hatchery contribution. Further quantification of the amount of natural reproduction may lead to a reduction in stocking levels while maintaining the total population at current levels.

Because varying proportions of hatchery steelhead are marked each year prior to release, estimates of hatchery fish in spawning runs based solely on counts of marked individuals may not adequately describe hatchery contribution. Given the differences in marking practices among states, the use of additional techniques, such as SPA to determine river or hatchery origin and genetic identification of hatchery strains, is necessary to provide a better representation of the contribution of hatchery individuals. Though SPA and genetic identification are more time intensive than simple observation of strain-specific marks, the differences in management practices necessitate the use of an additional technique to accurately identify nonmarked individuals so as to obtain useful management information.

\section{Acknowledgments}

The authors thank Jan Sapak, Neil Godby, and Brad Horne for assistance with sampling, the Wisconsin Department of Natural Resources and Gene Rhodes for providing samples, and Janel Palla, Steve Krueger, John Kubisiak, and Tom Burzynski for providing stocking information. Funding for M.L.B. was provided by the Fisheries Division of the Michigan Department of Natural Resources (MDNR) through the Federal Aid in Fisheries Restoration Act under Dingell-Johnson Project F-80R-3. Funding for K.T.S. was provided through the Partnership for Ecosystem Research and Management (PERM) program between the MDNR and Michigan State University.

\section{References}

Banks, M. A., M. S. Blouin, B. A. Baldwin, V. K. Rashbrook, H. A. Fitzgerald, S. M. Blankenship, and D. Hedgecock. 1999. Isolation and inheritance of novel microsatellites in Chinook salmon (Oncorhynchus tshawytscha). Journal of Heredity 90:281-288.

Bartron, M. L., and K. T. Scribner. 2004. Temporal comparisons of genetic diversity in Lake Michigan steelhead (Oncorhynchus mykiss) populations: effects of hatchery supplementation. Environmental Biology of Fishes 69:395-407.

Beacham, T. D., S. Pollard, and K. D. Le. 2000. Mi- crosatellite DNA population structure and stock identification of steelhead trout (Oncorhynchus mykiss) in the Nass and Skeena rivers in northern British Columbia. Marine Biotechnology 2:587-600.

Biette, R. M., D. P. Dodge, R. L. Hassinger, and T. M. Stauffer. 1981. Life history and timing of migrations and spawning behavior of rainbow trout ( $\mathrm{Sal}$ mo gairdneri) populations of the Great Lakes. Canadian Journal of Fisheries and Aquatic Sciences 38:1759-1771.

Blanchong, J. A., K. T. Scribner, and S. R. Winterstein. 2002. Assignment of individuals to populations: Bayesian methods and multilocus genotypes. Journal of Wildlife Management 66:321-329.

Burzynski, T. 1999. Wisconsin's Lake Michigan salmonid stocking program. Wisconsin Department of Natural Resources, Great Lakes Research Facility, Milwaukee.

Candy, J. R., and T. D. Beacham. 2000. Patterns of homing and straying in southern British Columbia coded-wire tagged Chinook salmon (Oncorhynchus tshawytscha) populations. Fisheries Research 47: 41-56.

Cornuet, J. M., S. Piry, G. Luikart, A. Estoup, and M. Solignac. 1999. Comparison of methods employing multilocus genotypes to select or exclude populations as origins of individuals. Genetics 153:19892000.

Dodge, D. P. 1972. Comparative bio-ecology of rainbow trout (Salmo gairdneri, Richardson) of three tributaries to the Owen Sound, Lake Huron. Doctoral dissertation. University of Guelph, Guelph, Ontario.

Efron, B. 1983. Estimating the error rate of a prediction rule: Improvement on cross-validation. Journal of the American Statistical Association 78:316-320.

Hansen, M. M., E. Kenchington, and E. E. Nielsen. 2001. Assigning individual fish to populations using microsatellite DNA markers. Fish and Fisheries 2:93112.

Hard, J. J., and W. R. Heard. 1999. Analysis of straying variation in Alaskan hatchery Chinook salmon (Oncorhynchus tshawytscha) following transplantation. Canadian Journal of Fisheries and Aquatic Sciences 56:578-589.

Marshall, A. R., M. Miller, C. Busack, and S. R. Phelps. 1991. Genetic stock identification analysis of three 1990 Washington ocean and Strait of Juan de Fuca Chinook salmon fisheries. Washington Department of Fisheries, GSI Summary Report 91- 1, Olympia.

Morris, D. B., K. R. Richard, and J. M. Wright. 1996. Microsatellites from rainbow trout (Oncorhynchus mykiss) and their use for genetic study of salmonids. Canadian Journal of Fisheries and Aquatic Sciences 53:120-126.

Nelson, R. J., T. D. Beacham, and M. P. Small. 1998. Microsatellite analysis of the population structure of a Vancouver Island sockeye salon (Oncorhynchus nerka) stock complex using nondenaturing gel electrophoresis. Molecular Marine Biology and Biotechnology 7:312-319.

Olsen, J. B., P. Bentzen, and J. E. Seeb. 1998. Characterization of seven microsatellite loci derived 
from pink salmon. Molecular Ecology 7:10871089.

Pascual, M. A., T. P. Quinn, and H. Fuss. 1995. Factors affecting the homing of fall Chinook salmon from Columbia River hatcheries. Transactions of the American Fisheries Society 124:308-320.

Pella, J. J., and G. B. Milner. 1987. Use of genetic marks in stock composition analysis. Pages $247-276$ in N. Ryman and F. Utter, editors. Population Genetics and Fishery Management. Washington Sea Grant, Seattle.

Potvin, C., and L. Bernatchez. 2001. Lacustrine spatial distribution of landlocked Atlantic salmon populations assessed across generations by multilocus individual assignment and mixed-stock analyses. Molecular Ecology 10:2375-2388.

Pritchard, J. K., M. Stephens, and P. Donnelly. 2000. Inference of population structure using multilocus genotype data. Genetics 155:945-959.

Quinn, T. P. 1993. A review of homing and straying of wild and hatchery-produced salmon. Fisheries Research 18:29-44.

Rand, P. S., D. J. Stewart, P. W. Seelbach, M. L. Jones, and L. R. Wedge. 1993. Modeling steelhead population energetics in Lakes Michigan and Ontario. Transactions of the American Fisheries Society 122: 977-1001.

Rannala, B., and J. L. Mountain. 1997. Detecting immigration using multilocus genotypes. Proceedings of the National Academy of Sciences of the USA 94:9197-9201.

Reisenbichler, R. R., and S. R. Phelps. 1989. Genetic variation in steelhead (Salmo gairdneri) from the north coast of Washington. Canadian Journal of Fisheries and Aquatic Sciences 46:66-73.

Rice, W. R. 1989. Analyzing tables of statistical tests. Evolution 43:223-225.

SAS Institute. 1999. SAS/STAT, version 8. 0. SAS Institute, Cary, North Carolina.

Scribner, K. T., P. A. Crane, W. J. Spearman, and L. W. Seeb. 1998. DNA and allozyme markers provide concordant estimates of population differentiation: analyses of U.S. and Canadian populations of $\mathrm{Yu}-$ kon River fall-run chum salmon (Oncorhynchus keta). Canadian Journal of Fisheries and Aquatic Sciences 55:1748-1758.

Scribner, K. T., J. R. Gust, and R. L. Fields. 1996. Isolation and characterization of novel salmon microsatellite loci: cross-species amplification and population genetic applications. Canadian Journal of Fisheries and Aquatic Sciences 53:833-841.

Seelbach, P. W. 1987. Smolting success of hatcheryraised steelhead planted in a Michigan tributary of Lake Michigan. North American Journal of Fisheries Management 7:223-231.

Seelbach, P. W. 1986. Population characteristics and dynamics of wild steelhead in a Michigan tributary of Lake Michigan. Doctoral dissertation. University of Michigan, Ann Arbor.

Seelbach, P. W., and B. R. Miller. 1993. Dynamics in Lake Superior of hatchery and wild steelhead emigrating from the Huron River, Michigan. Michigan Department of Natural Resources, Fisheries Division, Research Report 1993, Ann Arbor.

Seelbach, P. W., and G. E. Whelan. 1988. Identification and contribution of wild and hatchery steelhead stocks in Lake Michigan tributaries. Transactions of the American Fisheries Society 117:444-451.

Sokal, R. R., and F. J. Rohlf. 1995. Biometry, 3rd edition. Freeman, San Francisco.

Stauffer, T. M. 1955. Migration and growth of tagged, immature rainbow trout in the Black River, Mackinac County, and in Lake Michigan, 1951-1954. Michigan Department of Conservation, Institute of Fisheries Research Report 1441, Ann Arbor.

Thedinga, J. F., A. C. Wertheimer, R. A. Heintz, J. M. Maselko, and S. D. Rice. 2000. Effects of stock, coded-wire tagging, and transplant on straying of pink salmon (Oncorhynchus gorbuscha) in southeastern Alaska. Canadian Journal of Fisheries and Aquatic Sciences 57:2076-2085.

Waples, R. S. 1991. Genetic interactions between hatchery and wild salmonids: lessons from the Pacific Northwest. Canadian Journal of Fisheries and Aquatic Sciences 48(Supplement 1):124-133. 